\title{
Evidence of countergradient variation in the growth of an intertidal snail in response to water velocity
}

\author{
Geoffrey C. Trussell* \\ School of Marine Science, Virginia Institute of Marine Science, College of William \& Mary, Gloucester Point, Virginia 23062, USA
}

\begin{abstract}
Growth rates in rocky intertidal snails can vary considerably across wave exposure gradients, and have both plastic and genetic bases. However, little is known regarding whether genetic and environmental influences on variation in growth act in the same (cogradient) or in an opposing (countergradient) direction. Determining how genetic and environmental influences on growth covary with one another may improve our understanding of how habitat-specific variation in growth emerges. This study utilized laboratory flumes to examine the effects of high and low water velocities on the growth of intertidal snails Littorina obtusata from a wave-exposed and a sheltered shore. Both flow velocity and source population significantly influenced all measures of growth (shell length, shell thickness, shell mass and tissue mass). Snails from both populations exhibited greater growth in low versus high flow velocity. In addition, snails from the wave-exposed population grew more than snails from the sheltered population regardless of flow treatment. This result yielded a pattern of countergradient variation in growth and suggests that genetic differentiation between the 2 populations was responsible for the more rapid growth of wave-exposed snails. This greater growth potential of wave-exposed snails was particularly evident when they were raised in an environment conducive to rapid growth (i.e. low flow velocity). Most examples of countergradient variation in the growth of intertidal gastropods have involved temperature effects on latitudinally separated populations. This study provides evidence that countergradient variation in growth can occur on localized spatial scales in response to environmental cues other than temperature. On rocky intertidal shores, countergradient variation in growth may reflect selection for fast-growing genotypes to offset limitations on foraging time imposed by increased hydrodynamic stress on wave-exposed shores.
\end{abstract}

KEY WORDS: Cogradient variation · Countergradient variation · Foraging · Growth · Natural selection · Littorina obtusata $\cdot$ Plasticity $\cdot$ Predation $\cdot$ Wave energy

Resale or republication not permitted without written consent of the publisher

\section{INTRODUCTION}

Identifying the genetic and environmental basis of phenotypic variation has greatly improved our understanding of adaptation and the evolution of geographic variation. However, our knowledge of how genetic and environmental influences interact to produce patterns of phenotypic variation across environmental gradients remains limited. Recently, Conover \& Schultz

\footnotetext{
*Present address: Marine Science Center, Northeastern University, 430 Nahant Road, Nahant, Massachusetts 01908, USA. Email: g.trussell@neu.edu
}

(1995) suggested that attention to the covariance relationship between genetic and environmental influences, and subsequent effects on phenotypic expression, may provide a better understanding of how patterns of geographic variation emerge (see also Trussell \& Etter 2001). Reciprocal transplant or common garden experiments with individuals from populations occurring across the environmental gradient of interest (e.g. changing latitude) provide a powerful means of addressing this issue.

When there are both genetic and plastic influences on phenotypic expression in organisms distributed across an environmental gradient, 2 patterns are likely 
to emerge: cogradient and countergradient variation. Cogradient variation is more familiar to ecologists and arises when genetic and environmental influences have the same effects on phenotypic expression. Hence, cogradient variation often causes observable phenotypic variation across environmental gradients because environmental effects intensify the genetic influences on phenotypes (i.e. a positive covariance). Cogradient variation revealed by a reciprocal transplant experiment will show differentiation among phenotypes raised in their native environments. In addition, the phenotypes of transplanted individuals converge towards native phenotypes.

In contrast, countergradient variation typically causes little or no observable phenotypic variation across the environmental gradient because genetic and environmental effects on phenotypes oppose one another (i.e. a negative covariance). In addition, the phenotypes of transplanted organisms diverge from those of native phenotypes. Importantly, if countergradient patterns occur, then considerable genetic differentiation may exist among geographically separated populations despite the absence of phenotypic differentiation across the environmental gradient (Conover \& Schultz 1995). Hence, the presence of countergradient variation questions the assumption that the absence of clinal variation simply reflects genetic similarities among populations.

Cogradient variation is typically limited to morphological traits whereas countergradient variation is often found in physiologically based or life history traits (Conover \& Schultz 1995). Most examples of countergradient variation involve growth of organisms having wide altitudinal (Levins 1969, Berven et al. 1979, Berven 1982a,b) or latitudinal distributions (Dehnel 1955, 1956, Ament 1979, Conover \& Present 1990, Conover \& Schultz 1995, Parsons 1997, Trussell 2000, Craig \& Foote 2001), where dramatic temperature gradients are present. That temperature differences affect growth is not surprising (Cossins \& Bowler $1987)$ i in general, reduced temperatures are expected to suppress growth (Clarke 1983, Atkinson 1994). However, these studies have yielded the intriguing result that organisms from higher altitudes or latitudes (colder temperatures) exhibit growth rates that are comparable to those of conspecifics at lower altitudes and latitudes (warmer temperatures).

Levinton (1983) proposed the latitudinal compensation hypothesis to explain the comparable growth rates between high- and low-latitude organisms. Within a species, individuals from high-latitude populations have evolved the ability to grow more rapidly than low-latitude individuals at reduced temperatures; whereas low-latitude individuals grow more rapidly than high-latitude individuals at increased tempera- tures. This model has empirical support (Levinton 1983, Levinton \& Monahan 1983, Lonsdale \& Levinton 1985), but it cannot explain the more rapid growth of high-latitude versus low-latitude individuals at temperatures typical of low-latitude environments (Conover \& Present 1990, Conover \& Schultz 1995). Consequently, we have yet to arrive at a satisfactory explanation of why countergradient variation exists in natural populations, but it may arise due to trade-offs across different environments or different selection pressures among environments acting on the same trait (Conover \& Schultz 1995).

Intertidal snails exhibit remarkable morphological variation on both local and broad geographic scales (Kitching et al. 1966, Vermeij 1978, Vermeij \& Currey 1980, Trussell et al. 1993, Trussell 1997a,b, Boulding 1990, Boulding \& Van Alstyne 1993, Boulding et al. 1999). Considerable evidence indicates that these patterns can reflect both genetic differentiation (Kitching et al. 1966, Struthsaker 1968) and phenotypic plasticity (Appleton \& Palmer 1988, Etter 1988, Trussell 1996, 1997a, 2000, Trussell \& Nicklin 2002). Although not always recognized as such, there are examples of countergradient variation in the growth of latitudinally separated molluscan populations (Dehnel 1955, Ament 1979, Parsons 1997, Trussell 2000). As with other taxa, results of these studies appear to be tied to latitudinal differences in temperature. However, the presence of countergradient variation on more localized scales in response to environmental characteristics other than temperature has received little attention.

This study examined variation in the growth of the intertidal gastropod Littorina obtusata raised under different water velocities (hereafter, flow velocity) in the laboratory. I chose flow velocity because it is known to influence a number of snail life history traits (Brown \& Quinn 1988, Etter 1989, 1996). I found that countergradient variation in growth occurs across high and low flow velocity environments, thus providing evidence that it can evolve on micro-geographic spatial scales in response to environmental factors other than temperature.

\section{MATERIALS AND METHODS}

Laboratory flume experiment with Littorina obtusata. To examine the effects of source population and flow velocity on growth variation in Littorina obtusata, juvenile snails from a wave-exposed (East Point, Nahant, Massachusetts, $42^{\circ} 25.18^{\prime} \mathrm{N}, 70^{\circ} 54.14^{\prime} \mathrm{W}$ ) and a sheltered (Lobster Cove, Manchester, Massachusetts, $42^{\circ} 33.79^{\prime} \mathrm{N}, 70^{\circ} 46.19^{\prime} \mathrm{W}$ ) shore were raised under high and low flow velocities in experimental flumes (see Fig. 1 in Trussell 1997a). In early June 1998, juve- 
nile snails were collected from each shore and individually marked with indelible ink (Trussell 1997a). Initial shell length for each snail was measured as the maximum dimension of the shell parallel to the plane of the aperture (Trussell 1997a) and shell thickness was estimated as the mean of 2 measures made on the apertural lip of the shell (Trussell 1996). To determine initial shell mass and initial body mass (defined by wet tissue mass) of juvenile snails, I followed the nondestructive protocol of Palmer (1982). Using a Mettler (PG503) analytical balance, I measured the mass $( \pm 0.001 \mathrm{~g})$ of each snail while submerged in seawater (submerged mass) and then, after 30 min of drying in air, the total mass $( \pm 0.001 \mathrm{~g})$ of each snail in air. Actual shell mass $(\mathrm{Y})$ can be accurately predicted from submerged mass $(\mathrm{X})$ using regressions generated by a destructive sampling of snails from each population (East Point: $\mathrm{Y}=1.563 \mathrm{X}-0.003, \mathrm{R}^{2}=0.9992$; Lobster Cove: $\left.\mathrm{Y}=1.582 \mathrm{X}+0.0023, \mathrm{R}^{2}=0.9999\right)$. To calculate body mass, I subtracted the estimate of actual shell mass from the total mass of snails when weighed in air.

Twenty snails from each shore (Wave-exposed $=E_{\text {; }}$ Sheltered $=\mathrm{S}$ ) were placed in 4 replicate high flow velocity $(\mathrm{H})$ and 4 replicate low flow velocity $(\mathrm{L})$ flumes constructed from acrylic tubes $(0.81 \mathrm{~m}$ length $\times$ $58.5 \mathrm{~mm}$ in diameter). Flumes were connected to seawater reservoirs (400 l) with PVC pipe $(58.5 \mathrm{~mm}$ in diameter) and water flow through flumes was gravity driven (Trussell 1997a). To generate different flow velocities, the height of reservoirs above flumes was different for each treatment: high flow velocity reservoirs were $1.45 \mathrm{~m}$ above their flumes and low flow velocity reservoirs were $0.35 \mathrm{~m}$ above their flumes. An electronic timer that was programmed to open and close motorized solenoid ball valves every 2 min regulated wave events through flumes. This was the minimum interval possible without overheating the valves. Hence, during wave periods, snails in flumes were exposed to a wave event every $2 \mathrm{~min}$. When the motorized ball valves opened, a turbulent bore of water from each reservoir pulsed through their respective flumes for approximately $10 \mathrm{~s}$. Overall, during the $90 \mathrm{~d}$ of the experiment, snails in high and low velocity flumes were exposed to approximately 32000 wave events.

Feeding snails during the experiment required periods of reduced flow velocities, particularly in the high velocity treatment, because high flow prevented placement of food within the flumes. Hence, the experiment had feeding periods and wave periods that were alternated every 5 to $6 \mathrm{~d}$. Of the $90 \mathrm{~d}$ of the experiment, approximately $1 / 2$ were devoted to feeding periods and $1 / 2$ to wave periods. During feeding periods for both flow velocity treatments, $200 \mathrm{~g}$ wet mass of the alga
Ascophyllum nodosum were placed in each flume and water was allowed to trickle at low velocities $(\sim 1$ to $5 \mathrm{~cm} \mathrm{~s}^{-1}$ ) rather than pulse through the flumes as a turbulent bore.

Periods of high and low tide also were manipulated throughout the experiment by changing the fitting on the end of each flume. During high tide, an inverted PVC trap prevented flumes from draining. Removal of this trap during low tides allowed flumes to completely drain after each wave event. For logistical reasons, snails were exposed to only 1 low tide $(6$ to $8 \mathrm{~h}$ in duration) $\mathrm{d}^{-1}$. Because water within flumes during high tide slowed down the velocity of pulsing waves, there were differences in flow velocity between high and low tides. In high-velocity flumes flow velocity was $1.9 \mathrm{~m}$ $\mathrm{s}^{-1}$ during low tide and $1.7 \mathrm{~m} \mathrm{~s}^{-1}$ during high tide. In low-velocity flumes, flow velocity was $30 \mathrm{~cm} \mathrm{~s}^{-1}$ during low tide and $\sim 10 \mathrm{~cm} \mathrm{~s}^{-1}$ during high tide. Flow velocities were calculated as described in Trussell (1997a).

After $90 \mathrm{~d}$, snails were removed from the flumes and re-measured for shell length, shell thickness, shell mass and tissue mass using the methods described above. Growth increments were calculated by subtracting initial from final values.

Statistical analyses. Data from the flume experiment were analyzed with a 3-factor, nested analysis of covariance (ANCOVA) using JMP software for the Macintosh (Version 3.2.1, SAS 1995). Flow velocity treatment (high vs low) and source populations (waveexposed vs sheltered) were considered fixed effects. My response variable in all analyses was growth increment, and my covariates were the initial values of the particular trait being analyzed. Growth was determined for each snail within each flume. Because multiple snails within each flume are not independent, individual flumes were the experimental unit and were declared a random effect nested within flow treatment. This nested term was used by JMP to construct error mean squares, $F$-ratios and their respective degrees of freedom for main effects and their interaction. Slopes in all ANCOVA analyses were homogeneous (all $\mathrm{p}$ > $0.25)$.

\section{RESULTS}

For all measures of growth, Littorina obtusata exhibited countergradient variation across the 2 flow velocity treatments. Both wave-exposed and sheltered snails grew significantly more when raised under low flow velocity compared to those raised under high flow velocity (Table 1, Figs. 1 to 4). Source population also had a consistent significant effect on growth (Table 1). For shell length, shell thickness and shell mass growth, wave-exposed snails always grew more than sheltered 
Table 1. Results of ANCOVA on 4 measures of growth for wave-exposed (East Point, Nahant, MA) and sheltered (Lobster Cove, Manchester, MA) shore Littorina obtusata raised under high and low water velocities in laboratory flumes. ${ }^{*} \mathrm{p}<0.05,{ }^{* *} \mathrm{p}<0.01,{ }^{* * *} \mathrm{p}<0.001$

\begin{tabular}{|lcccc|}
\hline Source & df & MS & $F$ & Interpretation \\
\hline Shell length growth (Fig. 1) & & & \\
Flow (F) & 1,6 & 1.68 & $21.28^{* *}$ & Low > High \\
Population (P) & 1,288 & 6.40 & $209.30^{* * *}$ & Exposed $>$ Sheltered \\
F $\times$ P & 1,288 & 0.002 & 0.08 & \\
Replicate\{Flow $\}$ & 6,288 & 0.08 & $2.72^{*}$ & \\
Slope & 1,288 & 0.01 & 0.24 & \\
Shell thickness growth (Fig. 2) & & & \\
Flow (F) & 1,6 & $21.13 \times 10^{-2}$ & $6.25^{*}$ & Low $>$ High \\
Population (P) & 1,288 & $3.04 \times 10^{-2}$ & $20.26^{* * *}$ & Exposed $>$ Sheltered \\
F $\times$ P & 1,288 & $8.00 \times 10^{-4}$ & 0.53 & \\
Replicate\{Flow\} & 6,288 & $3.64 \times 10^{-3}$ & $2.43^{*}$ & \\
Slope & 1,288 & $4.60 \times 10^{-4}$ & 0.31 & \\
Shell mass growth (Fig. 3) & & & \\
Flow (F) & 1,6 & $3.00 \times 10^{-4}$ & $12.04^{* *}$ & Low $>$ High \\
Population (P) & 1,288 & $9.60 \times 10^{-4}$ & $68.90^{* * *}$ & Exposed $>$ Sheltered \\
F $\times$ P & 1,288 & $1.83 \times 10^{-6}$ & 0.13 & \\
Replicate\{Flow\} & 6,288 & $4.00 \times 10^{-5}$ & $3.00^{* *}$ & \\
Slope & 1,288 & $3.43 \times 10^{-6}$ & 0.25 & \\
Body mass growth (Fig. 4) & & & \\
Flow (F) & 1,6 & $2.90 \times 10^{-4}$ & $8.92^{* *}$ & Low $>$ High \\
Population (P) & 1,288 & $5.00 \times 10^{-5}$ & $5.79^{*}$ & Exposed $>$ Sheltered \\
F $\times$ P & 1,288 & $2.00 \times 10^{-5}$ & 1.83 & \\
Replicate\{Flow $\}$ & 6,288 & $4.00 \times 10^{-5}$ & $3.93^{* * *}$ & \\
Slope & 1,288 & $1.00 \times 10^{-5}$ & 1.26 & \\
& & & & \\
\hline
\end{tabular}

the 2 flow treatments. For example, although wave-exposed snails grew more than sheltered snails within each flow treatment, the tissue growth of sheltered snails raised in low flow velocity was greater than that of wave-exposed snails raised in high flow velocity.

For all growth analyses, I did not detect a significant population $\times$ flow treatment. Hence, changes in snail growth in response to both flow treatments were similar for snails from both populations.

\section{DISCUSSION}

Intraspecific variation in growth can have profound consequences to other life history traits such as the age and size of maturity (Stearns \& Koella 1986, Stearns 1992). Clearly variation in growth can have both genetic and environmental components, but knowledge of whether these components act in concert with or in opposition to one another across different environments may improve our understanding of how intraspecific differences in life histories snails, regardless of the flow velocity treatment (Figs. 1 to 3). However, a slightly different pattern emerged for tissue growth (Fig. 4) because the tissue growth of wave-exposed snails was not uniformly greater across

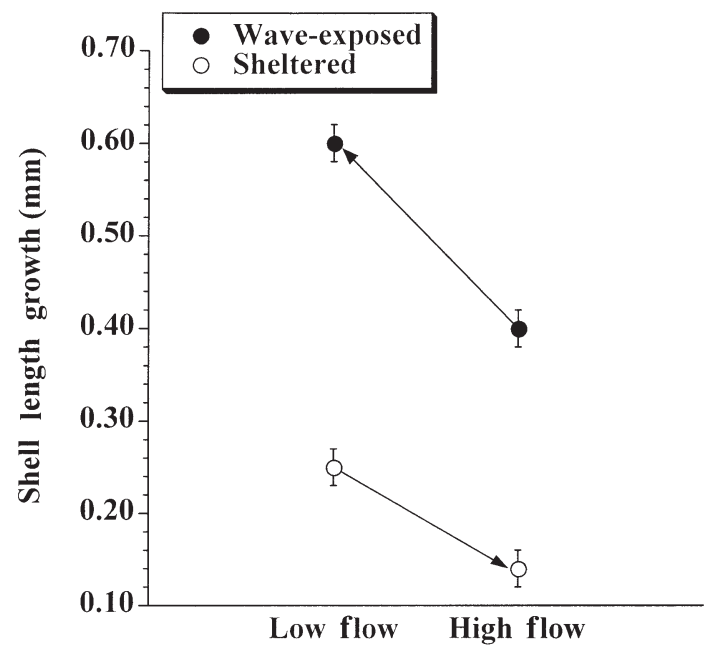

Fig. 1. Littorina obtusata. Least-squares adjusted means $( \pm \mathrm{SE})$ from ANCOVA for shell length growth of wave-exposed (E) and sheltered (S) individuals raised under high- and low-flow velocities in experimental flumes. See Table 1 for results of ANCOVA evolve. For rocky intertidal snails, spatial variation in wave energies is thought to be particularly important in driving intraspecific variation in both morphological (Kitching et al. 1966, Etter 1988, Trussell et al. 1993,

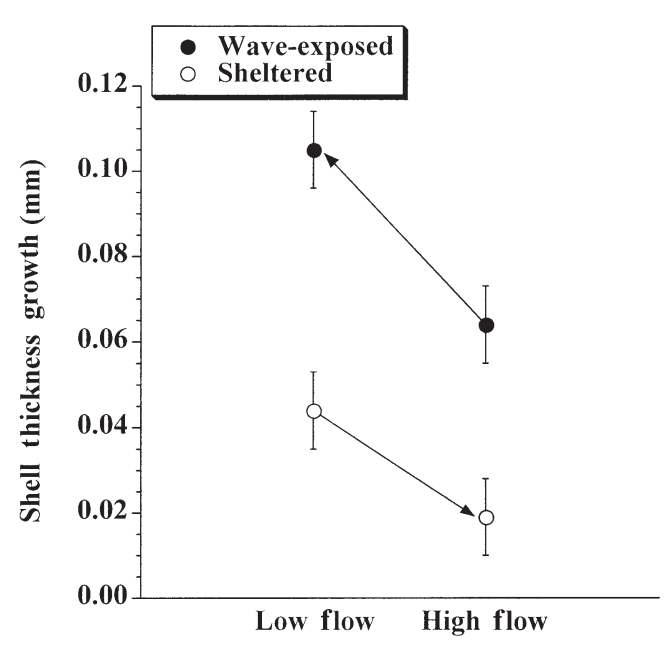

Fig. 2. Littorina obtusata. Least-squares adjusted means $( \pm \mathrm{SE})$ from ANCOVA for shell thickness growth of wave-exposed (E) and sheltered (S) individuals raised under high- and low-flow velocities in experimental flumes. See Table 1 for results of ANCOVA 


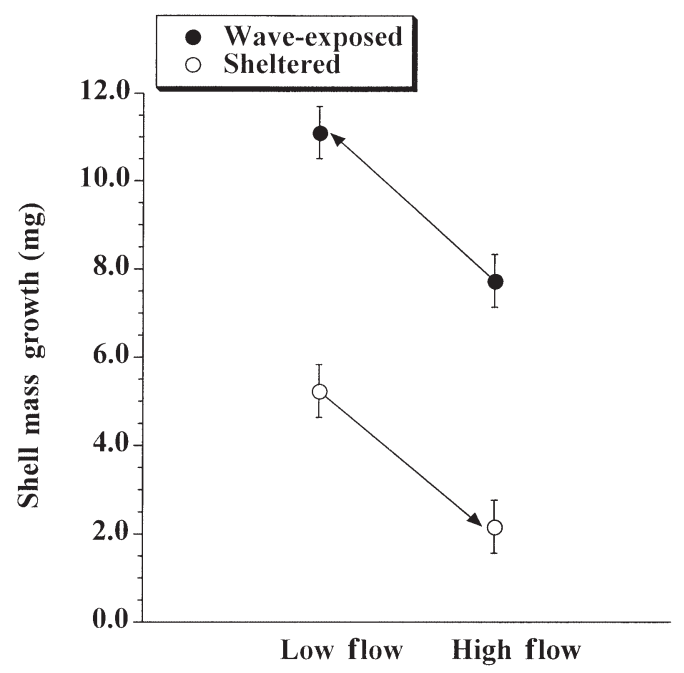

Fig. 3. Littorina obtusata. Least-squares adjusted means $( \pm \mathrm{SE})$ from ANCOVA for shell mass growth of wave-exposed (E) and sheltered (S) individuals raised under high- and low-flow velocities in experimental flumes. See Table 1 for results of ANCOVA

Trussell 1996, 1997a,b) and life history traits such as growth (Janson 1982, Brown \& Quinn 1988, Etter 1996), fecundity, and size at maturity (Etter 1989). In addition, morphological and life history variation across wave energy gradients appears to have both genetic and plastic bases (Janson 1982, Brown \& Quinn 1988, Etter 1988, 1996, Trussell 1996, 1997a). However, there has been little, if any, research explicitly addressing

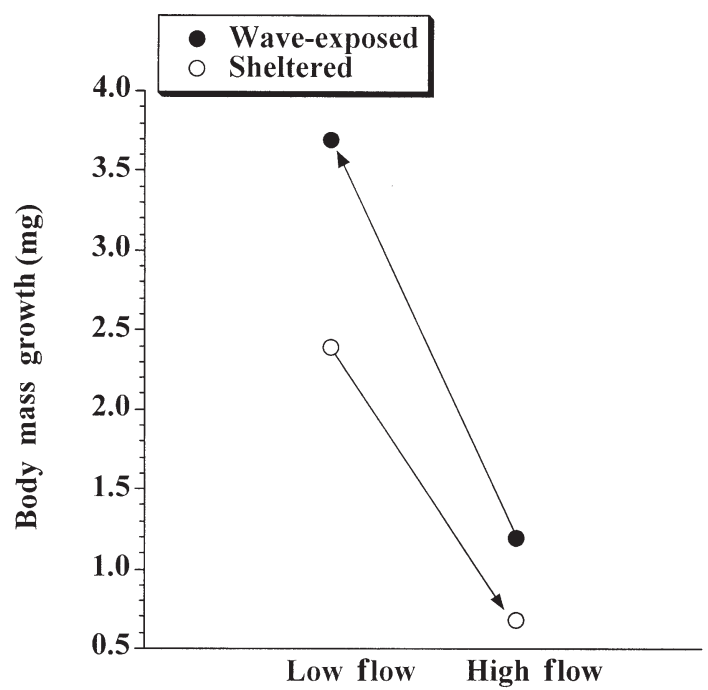

Fig. 4. Littorina obtusata. Least-squares adjusted means $( \pm \mathrm{SE})$ from ANCOVA for tissue mass growth of wave-exposed (E) and sheltered (S) individuals raised under high- and low-flow velocities in experimental flumes. See Table 1 for results of ANCOVA. Error bars are smaller than symbols how both factors interact to produce these patterns. This issue is important because the consequences of environmentally induced (plastic) variation in growth to other life history traits may be partly determined by whether plasticity in growth is reinforced (cogradient) or opposed (countergradient) by the prevailing selection regime (Fig. 5).

The influence of hydrodynamic forces accompanying breaking waves on intertidal snail morphology and life history is very likely mediated by differences in the risk of dislodgment on wave-exposed versus sheltered shores (Denny et al. 1985, Etter 1988, Trussell 1997a,b, Trussell et al. 1993). This risk should be greater on wave-exposed shores because the water velocities and accelerations accompanying breaking waves are much
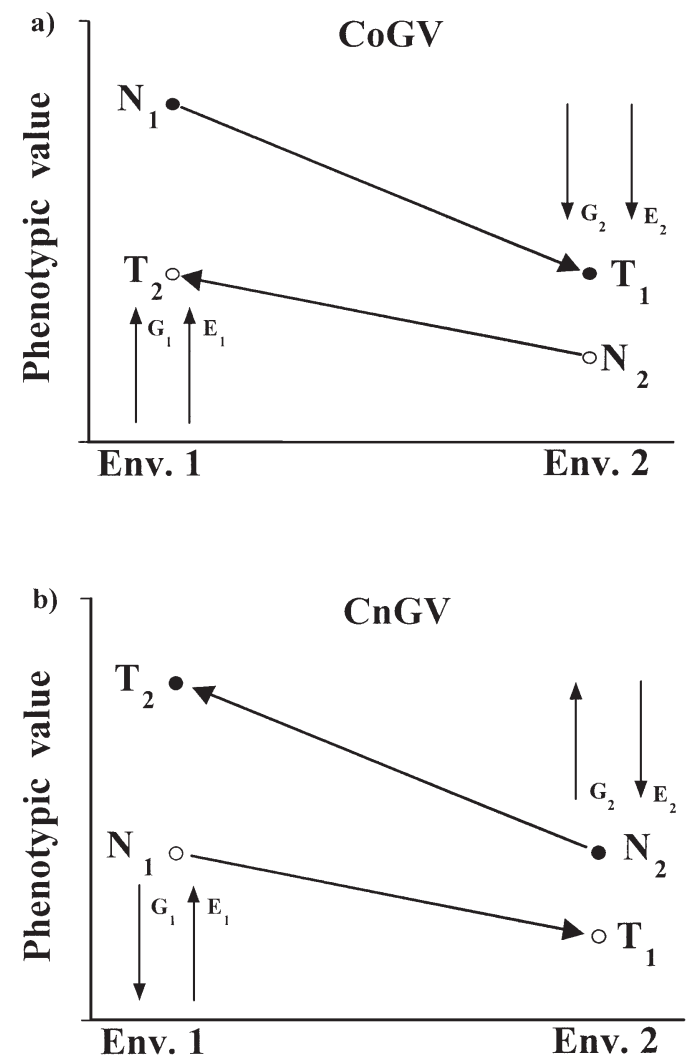

Fig. 5. Littorina obtusata. (a) Cogradient phenotypic variation. Note the large difference in phenotypic values of phenotypes in their native environments $\left(\mathrm{N}_{1}\right.$ and $\left.\mathrm{N}_{2}\right)$ and the shift of their respective transplants $\left(T_{1}\right.$ and $\left.T_{2}\right)$ towards the phenotypic values of native phenotypes. (b) Countergradient phenotypic variation. Note the similarity in phenotypic values of phenotypes in their native environments $\left(\mathrm{N}_{1}\right.$ and $\left.\mathrm{N}_{2}\right)$ and the divergences of their respective transplant phenotypes $\left(T_{1}\right.$ and $\left.T_{2}\right)$. Arrows with $\mathrm{G}$ and $\mathrm{E}$ refer to the direction of genetic and environmental influences on phenotypes within their respective environments. See 'Introduction' for further explanation (adapted from Conover \& Schultz 1995) 
greater compared to those typical of sheltered shores (Denny 1985, 1988, Denny et al. 1985, Denny \& Gaines 1990). Reducing this risk is thus paramount on waveexposed shores because dislodgment can reduce foraging time (Denny et al. 1985, Judge 1988), increase energy expenditures, or sweep snails into atypical habitats (e.g. the subtidal zone) with more diverse and efficient predator assemblages (Sebens 1981, Etter 1988). Consequently, snails on wave-exposed shores must restrict their foraging activity to periods when it is mechanically safe to do so, which results in reduced foraging time relative to conspecifics inhabiting sheltered shores. That snails remain stationary during periods of increased hydrodynamic stress is very likely tied to the reduction in tenacity that occurs when crawling (Miller 1974).

I found a countergradient pattern in all 4 measures of Littorina obtusata growth between the high- and low-flow velocity treatments (Figs. 1 to 4 ). Regardless of source population, snails always grew more in the low-flow velocity treatment compared to the highflow velocity treatment, suggesting that low-flow environments were conducive to more rapid growth. The countergradient pattern in snail growth emerged because wave-exposed snails consistently grew more than sheltered snails, even in the low-flow velocity treatment. This result suggests that genetic variation for more rapid growth in wave-exposed snails has been favored by natural selection compared to that favored for sheltered snails. This genetic capacity for increased growth in wave-exposed snails may have evolved to offset environmental constraints on feeding time imposed by increased hyrodynamic stress on wave-exposed shores. By raising wave-exposed snails in an environment more favorable to growth (i.e. reduced flow velocities and accelerations) this genetic potential can be fully expressed; for all measures of growth, wave-exposed snails raised in lowflow velocities grew the most of the 4 experimental groups.

Knowing how snails allocate deposited shell material is essential to a better understanding of how patterns in body growth may arise. Because snails must live within the shell they construct, shell size and thickness can constraint the amount of body mass capable of fitting inside the shell. Such architectural constraints are thought to be the primary reason for the reductions in body mass that accompany predator-induced increases in snail shell thickness (Appleton \& Palmer 1988, Palmer 1990, Trussell 1996, Trussell \& Smith 2000, Trussell \& Nicklin 2002). These architectural constraints arise because of a maximum limit to the rate of calcification (Palmer 1981, 1992); snails devoting more shell material to shell thickness do so at the expense of linear translation of the shell. In other words, thick-shelled snails generally grow less in terms of shell length than thin-shelled snails of similar shape (Kemp \& Bertness 1984, Trussell \& Nicklin 2002). Moreover, thick-shelled snails have less internal volume available for body growth than thin-shelled snails of similar size and shape.

Given these constraints, it may seem surprising that wave-exposed snails, compared to sheltered snails, consistently exhibited higher body mass growth despite their greater growth rate of shell thickness growth. However, one explanation for this result is that because shell thickness is positively correlated with shell length, the greater thickness growth of waveexposed snails may simply be a byproduct of their equally rapid growth in terms of shell length. Indeed, on average wave-exposed snails compared to sheltered snails grew $166 \%$ more in terms of shell thickness, $166 \%$ more in terms of shell length and $154 \%$ more in terms of shell mass. The close correspondence between these values supports the argument that the greater shell thickness and shell mass growth of waveexposed snails was a correlated response with shell length growth. These results also suggest that waveexposed snails were able to achieve more body growth despite their greater shell thickness growth because of the increases in internal shell volume afforded by increased shell length growth.

The faster growth in the shell mass of wave-exposed snails suggests that these snails are either more efficient at calcification than sheltered snails or that sheltered snails were not depositing shell material at a maximal rate. This result is counterintuitive because one would expect more intense crab predation, which is typical of sheltered shores (Boulding 1990, Boulding \& Van Alstyne 1993, Boulding et al. 1999), to favor greater calcification rates in sheltered snails. Presumably, selection would favor more rapid calcification rates in sheltered snails, allowing them to develop thicker shells quickly and reduce their risk of crab predation. However, I suspect that the lower overall shell deposition of sheltered snails may partly reflect the fact that they were significantly thicker than waveexposed snails at both the beginning (ANCOVA: $\left.F_{1,6}=4318.06 ; \mathrm{p}<0.0001\right)$ and end of the experiment (ANCOVA: $F_{1,6}=3704.52 ; \mathrm{p}<0.0001$ ). These population-specific differences in shell thickness may have constrained plasticity in the thickness growth of sheltered snails. Alternatively, sheltered snails may have been devoting more effort to body mass to compensate for the constraints imposed by their thicker shells. This scenario may be especially likely because there were no predator cues in the flumes that would have induced the continued production of thicker shells (Trussell 1996, 2000, Trussell \& Smith 2000, Trussell \& Nicklin 2002). 
I should note that the pattern of countergradient variation found here differs from typical examples (Conover \& Schultz 1995), because there were differences in growth between wave-exposed and sheltered snails raised in flow treatments which were meant to simulate the flow environments they may experience in the field ( $\mathrm{EH}$ vs $\mathrm{SL}$, respectively). Typically, with countergradient variation, one would expect to observe no differences in the growth between wave-exposed snails raised in high water velocities (EH) and sheltered snails raised in low water velocities (SL). However, although differences in water velocities within the experimental flumes induced plastic differences in growth, 'high' water velocities in the lab may have been perceived as low by wave-exposed snails compared to what they typically experience in the field (5 to $10 \mathrm{~m} \mathrm{~s}^{-1}$ or greater; Denny et al. 1985). Hence, the genetic capacity of wave-exposed snails for increased growth also may have been emerging in the high water velocity treatment and caused the observed differences in growth between EH and SL snails. Nevertheless, I observed countergradient variation in this study because the divergence in growth rate of snails raised in water velocities different than they typically experience was greater (EL and $\mathrm{SH}$ ) compared to the growth rate of snails raised in their 'native' environments (EH and SL).

Although not recognized as such, a reciprocal transplant experiment with 3 gastropod species between a wave-exposed and a sheltered shore in the California Pacific also yielded evidence of countergradient variation in growth (see Brown \& Quinn 1988). In this study, differences in growth between conspecifics raised on their native shores were considerably less than those revealed after transplanting. This pattern was most striking for Nucella emarginata, but qualitatively similar results also were found for Collisella digitalis and C. scabra. Like several other studies (Menge 1978, Roberts \& Hughes 1980, Hughes \& Drewett 1985, Burrows \& Hughes 1989), Brown \& Quinn (1988) argued that reduced growth on waveexposed shores may reflect restrictions on feeding time imposed by breaking waves. The argument that reductions in foraging time translate into reduced growth assumes that energy expenditures, assimilation efficiencies, and food quality and availability are similar among wave-exposed and sheltered environments. Although more work in this area is needed, Etter (1996) found that experimental inhibition of feeding in Nucella lapillus resulted in reduced growth rates, thus supporting the hypothesis that reduced growth rates on wave-exposed shores may partly reflect restricted feeding time imposed by increased hydrodynamic stress.
Because experimental feeding periods in both flow velocity treatments provided similar amounts of food, for the same amount of time, and relatively similar flow velocities, it would appear that actual feeding times were not different between the 2 flow velocity treatments. However, during the experiment, flumes in both treatments were quickly colonized by microflora (algae and diatoms) creating a natural food supply in addition to that provided experimentally. During wave periods, when Ascophyllum nodosum was not present in the flumes, there were obvious differences in snail behavior between flow velocity treatments. Snails in high flow velocities remained stationary and firmly attached to the flume walls. In contrast, snails in low flow velocities were able to move about the flumes, their rasping radula visibly indicating that they were feeding on microalgae and diatoms. Consequently, snails in low flow velocities had more actual feeding time than snails in high flow velocities. These observations are consistent with the hypothesis that differences in growth between the 2 flow velocity treatments arose because of flow-mediated differences in feeding time.

Although most examples of countergradient variation in marine gastropods have involved the effects of temperature on growth in latitudinally separated populations, my results suggest that this pattern can occur on localized spatial scales and in response to other environmental factors. However, the contrasting results of this study and others documenting both countergradient (Brown \& Quinn 1988) and cogradient (Janson 1982, Etter 1996) variation in growth preclude generalities regarding how genetic and environmental influences may shape variation in growth across different flow environments. Clearly attention to factors other than those that physically characterize the intertidal environment, such as behavior, may improve our understanding of the processes shaping habitatspecific differences in the growth of gastropods on intertidal shores.

Acknowledgements. I thank M. Bertness, E. Duffy, R. Etter, J. Milliman and M. Patterson for providing many helpful comments on previous drafts and J. Ayers at the Marine Science Center in Nahant for providing laboratory space. Special thanks to Ken Heck for his patience during revision of the manuscript. This work was supported by a National Science Foundation Dissertation Improvement Grant (Division of Environmental Biology), Sigma $\mathrm{Xi}_{1}$, the LernerGray Fund of the American Museum of Natural History, the Hawaiian Malacological Society, and Minor Research Grants from the Virginia Institute of Marine Science. Support during writing was provided by a Mellon Foundation Postdoctoral Fellowship and a grant from the National Science Foundation (Integrative Biology and Neurophysiology). 


\section{LITERATURE CITED}

Ament K (1979) Geographic variation in relation to life history in three species of the marine gastropod genus Crepidula: growth rates of newly hatched larvae and juveniles. In: Stancyk SE (ed) Reproductive ecology of marine invertebrates. University of South Carolina Press, Columbia, SC

Appleton RD, Palmer AR (1988) Water-borne stimuli released by crabs and damaged prey induce more predatorresistant shells in a marine gastropod. Proc Natl Acad Sci USA 85:4387-4391

Atkinson D (1994) Temperature and organism size: a biological law for ectotherms. Adv Ecol Res 25:1-58

Berven KA (1982a) The genetic basis of altitudinal variation in the wood frog Rana sylvatica. I. An experimental analysis of life history traits. Evolution 36:962-983

Berven KA (1982b) The genetic basis of altitudinal variation in the wood frog Rana sylvatica. II. An experimental analysis of larval development. Oecologia 52:360-369

Berven KA, Gill DE, Smith-Gill SJ (1979) Countergradient selection in the green frog, Rana clamitans. Evolution 33: $609-623$

Boulding EG (1990) Are the opposing selection pressures on exposed and protected shores sufficient to maintain genetic differentiation between gastropod populations with high intermigration rates? Hydrobiologia 193:41-52

Boulding EG, Van Alstyne KL (1993) Mechanisms of differential survival and growth of two species of Littorina on wave-exposed and protected shores. J Exp Mar Biol Ecol 169:139-166

Boulding EG, Holst M, Pilon V (1999) Changes in selection on gastropod shell size and thickness with wave-exposure on northeastern Pacific shores. J Exp Mar Biol Ecol 232: 217-239

Brown KM, Quinn JF (1988) The effect of wave action on growth in three species of intertidal gastropods. Oecologia 75:420-425

Burrows M, Hughes R (1989) Natural foraging of the dogwhelk, Nucella lapillus (Linnaeus); the weather and whether to feed. J Molluscan Stud 55:285-295

Clarke A (1983) Life in cold water: the physiological ecology of polar marine ectotherms. Oceanogr Mar Biol Annu Rev 21:341-453

Conover DO, Present TMC (1990) Countergradient variation in growth rate: compensation for length of the growing season among Atlantic silversides from different latitudes. Oecologia 83:316-324

Conover DO, Schultz ET (1995) Phenotypic similarity and the evolutionary significance of countergradient variation. Trends Ecol Evol 10:248-252

Cossins AR, Bowler K (1987) Temperature biology of animals. Chapman \& Hall, New York

Craig JK, Foote CJ (2001) Countergradient variation and secondary sexual color: phenotypic convergence promotes genetic divergence in carotenoid use between sympatric anadramous and nonanadramous morphs of sockeye salmon (Oncorhynchus nerka). Evolution 55:380-391

Dehnel P (1955) Rates of growth of gastropods as a function of latitude. Physiol Zool 28:115-144

Dehnel P (1956) Growth rates in latitudinally and vertically separated populations of Mytilus californianus. Biol Bull 110:43-53

Denny MW (1985) Wave forces and intertidal organisms: a case study. Limnol Oceanogr 30:1171-1187

Denny MW (1988) Biology and mechanics of the wave-swept environment. Princeton University Press, Princeton, NJ
Denny MW, Gaines SD (1990) On the prediction of maximal intertidal wave forces. Limnol Oceanogr 35:1-15

Denny MW, Daniel TL, Koehl MAE (1985) Mechanical limits to size in wave-swept organisms. Ecol Monogr 55: 69-102

Etter RJ (1988) Asymmetrical developmental plasticity in an intertidal snail. Evolution 42:322-334

Etter RJ (1989) Life history variation in the intertidal snail Nucella lapillus across a wave-exposure gradient. Ecology 70:1857-1876

Etter RJ (1996) The effect of wave action, prey type, and foraging time on growth of the predatory snail Nucella lapillus (L.). J Exp Mar Biol Ecol 196:341-356

Hughes RN, Drewett D (1985) A comparison of the foraging behavior of dogwhelks, Nucella lapillus (L.), feeding on barnacles or mussels on the shore. J Molluscan Stud 51: 73-77

Janson K (1982) Genetic and environmental effects on the growth rate of Littorina saxatilis. Mar Biol 69:73-78

Judge ML (1988) The effects of increased drag on Lottia gigantea (Sowerby 1834) foraging behavior. Funct Ecol 2:363-369

Kemp P, Bertness MD (1984) Snail shape and growth rates: evidence for plastic allometry in Littorina littorea. Proc Natl Acad Sci USA 81:811-813

Kitching JA, Muntz L, Ebling FJ (1966) The ecology of Lough Ine. XV. The ecological significance of shell and body forms in Nucella. J Anim Ecol 35:113-126

Levins R (1969) Thermal acclimation and heat resistance in Drosophila species. Am Nat 103:483-499

Levinton JS (1983) The latitudinal compensation hypothesis: growth data and a model of latitudinal growth differentiation based upon energy budgets. I. Interspecific comparison of Ophryotrocha puerlis (Polychaeta: Dorvilleidae). Biol Bull 165:686-698

Levinton JS, Monahon RK (1983) The latitudinal compensation hypothesis: growth data and a model of latitudinal growth differentiation based upon energy budgets. II. Intraspecific comparisons between subspecies of Ophryotrocha puerlis (Polychaeta: Dorvilleidae). Biol Bull 165: 699-707

Lonsdale DJ, Levinton JS (1985) Latitudinal differentiation in copepod growth: an adaptation to temperature. Ecology 66:1397-1407

Menge BA (1978) Predation intensity in a rocky intertidal community: effect of an algal canopy, wave action and desiccation on predator feeding rates. Oecologia 34:17-35

Miller SL (1974) Adaptive design of locomotion and foot form in Prosobranch gastropods. J Exp Mar Biol Ecol 14:99-156

Palmer AR (1981) Do carbonate skeletons limit the rate of body growth? Nature 292:150-152

Palmer AR (1982) Growth in marine gastropods: a nondestructive technique for independently measuring shell and body weight. Malacologia 23:63-73

Palmer AR (1990) Effect of crab effluent and scent of damaged conspecifics on feeding, growth, and shell morphology of the Atlantic dogwhelk Nucella lapillus (L.). Hydrobiologia 193:155-182

Palmer AR (1992) Calcification in marine mollusks: how costly is it? Proc Natl Acad Sci USA 89:1379-1382

Parsons KE (1997) Contrasting patterns of heritable geographic variation in shell morphology and growth potential in the marine gastropod Bembicium vittatum: evidence from field experiments. Evolution 51:784-796

Roberts DJ, Hughes RN (1980) Growth and reproductive rates of Littorina rudis from three contrasted shores in North Wales, UK. Mar Biol 58:47-54 
SAS (1995) JMP users' guide, Version 3.2.1. SAS Institute, Cary, NC

Sebens KP (1981) Recruitment in a sea anemone population: juvenile substrate becomes adult prey. Science 213: 785-787

Stearns SC (1992) The evolution of life histories. Oxford University Press, New York

Stearns SC, Koella JC (1986) The evolution of phenotypic plasticity in life-history traits: predictions of reaction norms for age and size at maturity. Evolution 40:893-913

Struthsaker JW (1968) Selection mechanisms associated with interspecific shell variation in Littorina picta (Prosobranchia: Mesogastropoda). Evolution 22:459-480

Trussell GC (1996) Phenotypic plasticity in an intertidal snail: the role of a common crab predator. Evolution 50:448-454

Trussell GC (1997a) Phenotypic plasticity in the foot size of an intertidal snail. Ecology 78:1033-1048

Trussell GC (1997b) Phenotypic selection in an intertidal snail: the effects of a catastrophic storm. Mar Ecol Prog Ser 151:73-79

Editorial responsibility: Kenneth Heck (Contributing Editor), Dauphin Island, Alabama, USA
Trussell GC (2000) Phenotypic clines, plasticity and trade-offs in an intertidal snail. Evolution 54:151-166

Trussell GC, Etter RJ (2001) Integrating genetic and environmental forces that shape the evolution of geographic variation in a marine snail. Genetica 112/113:321-337

Trussell GC, Nicklin MO (2002) Cue sensitivity, inducible defense, and trade-offs in a marine snail. Ecology 83: $1635-1647$

Trussell GC, Smith LD (2000) Induced defenses in response to an invading crab predator: an explanation of historical and geographic phenotypic change. Proc Natl Acad Sci USA 97:2123-2127

Trussell GC, Johnson AS, Rudolph SG, Gilfillan ES (1993) Resistance to dislodgment: habitat and size-specific differences in morphology and tenacity in an intertidal snail. Mar Ecol Prog Ser 100:135-144

Vermeij GJ (1978) Evolution and escalation: an ecological history of life. Princeton University Press, Princeton, NJ

Vermeij GJ, Currey JD (1980) Geographical variation in the strength of Thaidid snail shells. Biol Bull 158:383-389

Submitted: October 23, 2000; Accepted: July 18, 2002

Proofs received from author(s): October 16, 2002 